\title{
CLINICAL AND LABORATORY CHARACTERISTICS OF NEONATAL CANDIDA SEPSIS
}

\author{
Hadzic Devleta, ${ }^{1}$ Skokic Fahrija, ${ }^{1}$ Brkic Selmira, ${ }^{2}$ Saracevic Amina ${ }^{1}$ \\ ${ }^{1}$ Pediatric Clinic, University Clinical Center of Tuzla, Bosnia and Herzegovina \\ ${ }^{2}$ Faculty of Medicine University of Tuzla, Bosnia and Herzegovina
}

Primljen/Received 05. 09. 2019. god.

Abstract: Introduction: Steady progress in intensive treatment worldwide has increased the survival of immature neonates, but with multiple invasive procedures, which has increased the risk of infection and, consequently, fungal sepsis. Candida is the dominant cause, with the rise of resistant non-albicans species. The mortality rate is high and requires timely suspicion and adequate treatment to counteract fatal outcomes.

Objectives:To analyze the clinical and laboratory characteristics of Candida sepsis, compared to bacterial sepsis, in neonates treated in the neonatal intensive care unit. Methods: A retrospective cohort study conducted at the Intensive care unit of Pediatric Clinic Tuzla over a three-year period (2016-2018) analyzed the clinical and laboratory characteristics of neonates with Candida sepsis, evidenced by positive blood culture. The control group was neonates treated at the same time for proven bacterial sepsis. Statistical analysis applied standard methods, and the research was approved by the Ethics Committee of the institution.

Results: Out of the total 921 neonates treated over a three-year period, culture-confirmed Candida sepsis was found in $48(5.2 \%)$. Prematurity and low birth weight were the most significant risk factors and affected neonates had a more difficult clinical presentation, more receiving parenteral nutrition, mechanical ventilation, intravenous gamma globulin, and longer intensive treatment. Candida sepsis manifested mainly as late-onset. Laboratory abnormalities mainly included CRP elevation, anemia, leukocyte count deviations, and thrombocytopenia. There was no difference in mortality, 44 neonates recovered (91.7\%), while 4 ( $8.3 \%$ ) died. Antifungal therapy lasted $20.6 \pm 6$ days, and intensive treatment $38.2 \pm 23.2$ days, and was significantly longer compared to the control. All isolates were Candida species without in vitro resistance. In 8 neonates $(16.7 \%)$ treatment complications were recorded.
Prihvaćen/Accepted 12. 10. 2019. god.

Conclusions: Neonatal Candida sepsis endangers life, complicates treatment, increases costs and mortality rate. Recovery depends on timely suspicion, adequate treatment, and supervision. Antifungal susceptibility is also important and requires monitoring of local epidemiological dynamics.

Key words: Candida sepsis, neonates, clinical and laboratory characteristics.

\section{INTRODUCTION}

Fungal sepsis is increasingly reported in neonates at tertiary neonatal care centers, and althought is less common compared to bacterial Gram-positive and Gram-negative sepsis, it has a higher mortality rate, especially in preterm infants with low birth weight, while infants who survive often have long-term neurological damage (1-5).

Candida is most commonly reported causative agents of neonatal fungal sepsis, but instead of the previously dominant (up to $80 \%$ ) sensitive Candida albicans, today non-albicans Candida types are increasingly reported, including C. parapsilosis, C.tropicalisi C. glabrata that show varying degrees of resistance to fluconazole and other antifungal agents $(6,7,8)$. It is very important to have current information on neonatal fungal isolates and their patterns of antimicrobial susceptibility, and thus be guided in the choice of empirical antifungal therapy $(9,10,11)$.

The mortality rate is different and ranges from $20-75 \%(12,13)$. The risk factors for neonatal fungal sepsis have been extensively studied and include prematurity, low birth weight, indwelling central venous catheter use, prolonged hospitalization, mechanical ventilation, endotracheal intubation, parenteral nutrition, prolonged broad-spectrum antibiotic use, exposure to H2- receptor antagonist, as well as previous Candida albicans colonization from mother (13-17). 
Clinical presentations of fungal sepsis have also been investigated and were found usually as non-specific in neonates, including thrombocytopenia, lethargy, glucose instability, increased requirements for ventilation or apnea (16). The outcome depends mainly on early and in time identified cause, as well as the adequate causal therapy started in time. The definite diagnosis of fungal sepsis is not always easy to confirm because isolation and identification of the pathogen take time. Empirical antifungal therapy is based on local epidemiology monitoring of dominant agents in a particular unit $(10,11,12)$. For rapid evaluation and decision, clinicians retaina combination of clinical and laboratory findings as a diagnostic tool for the evaluation of neonatal fungal sepsis.

The aim of this study was to determine the clinical and laboratory characteristics of neonatal confirmed candida sepsis in comparison with non-fungal neonatal sepsis.

\section{PATIENTS AND METHODS}

A retrospective cohort study, which included all consecutive neonates with positive blood culture, from those treated in the Neonatal intensive care unit (NICU) of Pediatric clinic Tuzla (capacity 20 beds, level III) over a three-year period (2016 to 2018). All neonates with Candida positive blood culture were designated as the test group. The control group consisted of neonates with a non-fungal positive blood culture. The study was approved by the Ethics Committee of the Institution.

Clinical and demographic data were obtained from medical records and electronic database of patients treated in the NICU, which included gender, gestational age, birth weight, perinatal risk factors, clinical presentation, laboratory findings, applied therapy, and the outcome. During admission, the clinical status of neonates was scored by SNAP-PE (Score for Neonatal Acute Physiology - Perinatal Extension) and CRIB II (Clinical Risk Index for Babies) score (18). Especially analyzed predisposing factors for fungal neonatal sepsis ( presence of a central venous catheter, length of mechanical ventilation treatment, antibiotic therapy, parenteral nutrition and length of hospitalization).

Among laboratory findings we particularly analyzed potential markers of infection, including C-reactive protein (CRP), Complete blood cell (CBC) counts, the highest and lowest value for white blood cell (WBC) count, absolute neutrophil count (ANC), immature -tototal neutrophil ratio (I/T ratio), platelet count, and coagulation status.

The early onset of neonatal sepsis was defined as an infection that develops in the first 7 days of life, and late-onset of neonatal sepsis was defined as an infection that develops after the 7 th day of life. The long- term antibiotics use was considered if it exceeded 14 days of continuous administration. Fluconazole was used as the first line of empirical antifungal therapy. There was no prophylactic administration of Fluconazole in NICU at the study time, and empiric antibiotic therapy for neonatal sepsis was Ceftazidime, Amikacin, which was corrected by Meropenem and/or Vancomycin, depending on further clinical course and findings in a particular patient.

All data were analyzed and compared in two groups of neonates, those with confirmed Candida sepsis were compared with a group of neonates with confirmed no fungal sepsis. For statistical analysis of data standard methods of descriptive statistics (central tendency measures, dispersion measures) were used. Parametric and non- parametric significance tests $\left(\mathrm{X}^{2}\right.$-test, Student's t- test), as well as linear correlation method, were used to test the significance of differences between the samples. Statistical hypotheses were tested at a significance level of $\alpha=0.05$, i.e. the difference between the samples is considered significant if $\mathrm{P}<0.05$. We used Systat Software, SystatInc, Evanstan, IL, USA for statistical processing of data.

\section{RESULTS}

During the three- year period, 921 neonates were treated in NICU, and their basic clinical and demographic characteristics are shown in Table 1.

Out of a total of 921 treated neonates, Candida sepsis was found in 48 neonates $(5.2 \%)$, evenly found in both genders. The basic clinical and demographic data of neonates treated for Candida sepsis are shown in the Table 2 compared to neonates with non-fungal

Table 1. NICU admitted patients characteristics $(n=921)$

\begin{tabular}{|l|c|c|}
\hline Characteristics & $\mathbf{n}$ & $\mathbf{\%}$ \\
\hline neonates & 921 & 100.0 \\
\hline preterm & 501 & 54.4 \\
\hline late preterm & 328 & 35,6 \\
\hline very preterm & 173 & 18.7 \\
\hline extremely preterm & 58 & 6.2 \\
\hline low birth weight & 278 & 30.1 \\
\hline very low birth weight & 116 & 12.5 \\
\hline extremely low birth weight & 38 & 4.1 \\
\hline Mechanical ventilation within NICU stay & 330 & 35.8 \\
\hline Surgery within NICU stay & 46 & 4.9 \\
\hline Clinically confirmed sepsis & 396 & 42.9 \\
\hline Confirmed sepsis on blood cultures & 235 & 25.5 \\
\hline Confirmed fungal sepsis on blood cultures & 48 & 5.2 \\
\hline \multicolumn{2}{|c|}{ NICU: neonatal intensive care unit } \\
\hline
\end{tabular}


Table 2. Baseline characteristics of fungal and non-fungal cases

\begin{tabular}{|c|c|c|c|}
\hline Variables & $\begin{array}{l}\text { Fungal Sepsis } \\
\quad(n=48)\end{array}$ & $\begin{array}{l}\text { Non-fungal sepsis } \\
(\mathrm{n}=187)\end{array}$ & $\mathbf{p}$ \\
\hline \multicolumn{4}{|l|}{ Gestational age } \\
\hline preterm & $42(87.5)$ & $80(42.8)$ & $<0.001$ \\
\hline late preterm & $11(22.9)$ & $41(21.9)$ & 0.8816 \\
\hline very preterm & $31(64.6)$ & $39(20.9)$ & $<0.001$ \\
\hline extremely preterm & $8(16.7)$ & $5(2.7)$ & 0.0002 \\
\hline \multicolumn{4}{|l|}{ Birth weight } \\
\hline low birth weight & $39(81.25)$ & $64(34.2)$ & $<0.001$ \\
\hline very low birth weight & $20(41.7)$ & $11(5.9)$ & $<0.001$ \\
\hline extremely low birth weight & $4(8.3)$ & $2(1.1)$ & 0.0049 \\
\hline \multicolumn{4}{|l|}{ Gender } \\
\hline Male & $25(52.1)$ & $116(62.0)$ & 0.2117 \\
\hline female & $23(47.9)$ & $71(38.0)$ & 0.2117 \\
\hline \multicolumn{4}{|l|}{ Mode of delivery: } \\
\hline cesarean section & $18(37.5)$ & $67(35.8)$ & 0.8269 \\
\hline vaginal & $30(62.5)$ & $120(64.2)$ & 0.8269 \\
\hline \multicolumn{4}{|l|}{ Maternal risk factors: } \\
\hline No & $8(16.7)$ & $104(55.6)$ & $<0.001$ \\
\hline EPH gestosis & $7(14.6)$ & $23(12.3)$ & 0.6702 \\
\hline Diabetes mellitus & $1(2.1)$ & $3(1.6)$ & 0.8112 \\
\hline Infection & $8(16.7)$ & $32(17.1)$ & 0.9476 \\
\hline In vitro fertilization & $2(4.2)$ & $8(4.3)$ & 0.9756 \\
\hline Premature rupture of membrane & $4(8.3)$ & $40(21.4)$ & 0.038 \\
\hline
\end{tabular}

Table 3. Compared data of fungal and non-fungal cases

\begin{tabular}{|c|c|c|c|c|c|}
\hline \multirow{2}{*}{ Parameter } & \multicolumn{2}{|c|}{ Fungal sepsis } & \multicolumn{2}{|c|}{ Non-fungal sepsis } & \multirow{2}{*}{$\mathbf{p}$} \\
\hline & Mean & SD & Mean & SD & \\
\hline GA (weeks) & 32.35417 & 3.789625 & 36.26738 & 3.279646 & $<0.001$ \\
\hline BW (grams) & 1852.083 & 746.2700 & 2841.781 & 805.9642 & $<0.001$ \\
\hline $\mathrm{AS} 1^{\text {st }}$ minute & 5.904762 & 2.119074 & 6.989305 & 2.369132 & 0.0042 \\
\hline AS $5^{\text {th }}$ minute & 6.952381 & 1.321975 & 7.780749 & 1.675264 & 0.0017 \\
\hline PRM (hours) & 4.095238 & 4.134063 & 5.189840 & 11.34193 & 0.5121 \\
\hline $\mathrm{CRP}(\mathrm{mg} / l)$ & 49.54792 & 70.13882 & 21.69626 & 40.06281 & 0.0004 \\
\hline Htc & 0.506190 & 0.093353 & 0.515684 & 0.107224 & 0.5753 \\
\hline Leukocytes & 9.190476 & 3.756182 & 14.12230 & 8.439908 & 0.0001 \\
\hline neutrophils & 0.320952 & 0.148017 & 0.4096989 & 0.1862285 & 0.0025 \\
\hline ANC & 3250.000 & 2240.187 & 6056.701 & 4551.286 & $<0.001$ \\
\hline ITR & 0.074762 & 0.061937 & 0.081979 & 0.096580 & 0,7834 \\
\hline platelets & 110.6667 & 97.57361 & 223.2781 & 116.6098 & $<0.001$ \\
\hline albumin & 26.42857 & 4.632186 & 27.57219 & 4.219511 & 0.1021 \\
\hline Treatment (days) & 38.19048 & 23.14653 & 12.40107 & 6.930112 & $<0.001$ \\
\hline CRIB II & 5.952381 & 4.318289 & 3.941176 & 4.078763 & 0.0029 \\
\hline SNAPEPE II & 36.80952 & 20.07889 & 23.51337 & 24.99298 & 0.0008 \\
\hline
\end{tabular}


Table 4. Clinical characteristics of fungal and non-fungal cases

\begin{tabular}{|l|c|c|c|}
\hline \multicolumn{1}{|c|}{ Variables } & $\begin{array}{c}\text { Fungal Sepsis } \\
(\mathbf{n}=\mathbf{4 8})\end{array}$ & $\begin{array}{c}\text { Non-fungal sepsis } \\
(\mathbf{n = 1 8 7})\end{array}$ & p-value \\
\hline CRIB II (mean \pm SD) & $5,95 \pm 4,32$ & $3,94 \pm 4,08$ & $\mathbf{0 . 0 0 2 9}$ \\
\hline SNAPEPE II (mean \pm SD) & $36,81 \pm 20,08$ & $23,51 \pm 24,99$ & $\mathbf{0 . 0 0 0 8}$ \\
\hline Early onset of sepsis (<3 days) & 0 & $76(40.6 \%)$ & $<\mathbf{0 . 0 0 0 1}$ \\
\hline Early onset of sepsis $(<7$ days) & $3(6.2 \%)$ & $112(59.9)$ & $<\mathbf{0 . 0 0 0 1}$ \\
\hline Late onset of sepsis $(>7$ days) & $45(93.8 \%)$ & $75(40.1 \%)$ & $<\mathbf{0 . 0 0 0 1}$ \\
\hline Broad spectrum antibiotics $>3$ n (\%) & $10(20.8)$ & $53(28.3)$ & 0.2951 \\
\hline Probiotics n (\%) & $12(25.0)$ & $42(22.5)$ & 0.7136 \\
\hline intravenous immunoglobulins n (\%) & $14(29.2)$ & $27(14.4)$ & $\mathbf{0 . 0 1 5 9}$ \\
\hline ursodeoxycholic acid n (\%) & $8(16.7)$ & $11(5.9)$ & $\mathbf{0 . 0 1 4 5}$ \\
\hline Mechanical ventilation n (\%) & $43(89.6)$ & $39(20.8)$ & $<\mathbf{0 . 0 0 1}$ \\
\hline Parenteral nutrition n (\%) & $48(100.0)$ & $63(33.7)$ & $<\mathbf{0 . 0 0 1}$ \\
\hline Inotropes n $(\%)$ & $15(31.25)$ & $57(30.48)$ & 0.9178 \\
\hline NICU stay in days (mean \pm SD) & $38,19 \pm 23,15$ & $12,40 \pm 6,93$ & $<\mathbf{0 . 0 0 1}$ \\
\hline Outcome & & & 0.5442 \\
\hline Survivors n (\%) & $44(91.7)$ & $176(94.1)$ & 0.5442 \\
\hline Non-survivors n (\%) & $4(8.3)$ & $11(5.9)$ & \\
\hline $\begin{array}{l}\text { CRIB II - Clinical Risk Index for Babies scoring system; SNAPEPE II - Score for Neonatal Acute Physiology-Perinatal Extensi- } \\
\text { on; SD - standard deviation; NICU - Neonatal intensive care unit }\end{array}$ \\
\hline
\end{tabular}

Table 5. Laboratory characteristics of fungal and non-fungal because

\begin{tabular}{|l|c|c|c|}
\hline \multicolumn{1}{|c|}{ Variables } & $\begin{array}{c}\text { Fungal Sepsis } \\
(\mathbf{n = 4 8 )}\end{array}$ & $\begin{array}{c}\text { Non-fungal sepsis } \\
(\mathbf{n = 1 8 7 )}\end{array}$ & p-value \\
\hline $\mathrm{CRP}<5 \mathrm{mg} / l$ & $15(31.3)$ & $100(53.5)$ & $\mathbf{0 . 0 0 6 1}$ \\
\hline $\mathrm{CRP}>5 \mathrm{mg} / l$ & $33(68.8)$ & $87(46.5)$ & $\mathbf{0 . 0 0 5 8}$ \\
\hline Htc anemia & $19(39.6)$ & $7(3.7)$ & $<\mathbf{0 . 0 0 1}$ \\
\hline Htc normalž & $21(43.8)$ & $138(73.8)$ & $\mathbf{0 . 0 0 0 1}$ \\
\hline Htc polycythemia & $8(16.7)$ & $42(22.5)$ & 0.3814 \\
\hline Leukocytes $<6$ & $17(35.4)$ & $28(15.0)$ & $\mathbf{0 . 0 0 1 4}$ \\
\hline Leukocytes $>13$ & $31(64.6)$ & $75(40.1)$ & $\mathbf{0 . 0 0 2 3}$ \\
\hline ANC $<1800$ & $10(20.8)$ & $38(20.3)$ & 0.9389 \\
\hline ANC $>13000$ & $4(8.3)$ & $24(12.8)$ & 0.39 \\
\hline Platelets $<150$ & $38(79.2)$ & $50(26.7)$ & $<\mathbf{0 . 0 0 1}$ \\
\hline Platelets $>450$ & $1(2.1)$ & $7(3.7)$ & 0.5839 \\
\hline coagulation status normal & $25(52.1)$ & $102(54.5)$ & 0.766 \\
\hline coagulation status disrupted & $23(47.9)$ & $85(45.5)$ & 0.766 \\
\hline CRP - C reactive protein; Htc - hematocrit; ANC - Absolute neutrophil count \\
\hline
\end{tabular}

sepsis. Mostly, Candida sepsis was found in preterm infants with a low birth weight with an average gestational age of $32.3 \pm 3.7$ and a birth weight of $1852 \pm 746$ grams (Table 3). Neonates from the Candida sepsis group, compared to the non fungal sepsis group (Table
3), had slightly lower values of Apgar score in the first and fifth minutes.

Prematurity and low birth weight in our study were confirmed as the most significant perinatal risk factors for the onset of Candida sepsis in critically ill in- 
fants (Table 4). More precisely, very preterm and extremely preterm neonates were significantly more frequent in the group of Candida sepsis compared to the non-fungal sepsis group. Low birth weight, very low birth weight, and extremely low birth weight neonates were significantly more frequent in the Candida sepsis group compared to the non-fungal sepsis group. Gender and mode of delivery did not seem to havea significant difference between groups. Maternal risk factors showed low significance, so "no-risk" and prolonged rupture of the membrane was slightly more common in the non-fungal sepsis group.

Neonatal disease severity scoring systems (CRIB II and SNAPE-PE II) were applied at admission for each neonate. Both scoring systems showed significantly higher values in neonates with Candida sepsis in relation to the non-fungal sepsis group. The severe clinical presentation of neonates with proven sepsis via positive blood culture was demonstrated by the necessarily applied supportive therapy shown in Table 3. Clinically, fungal sepsis manifested as late sepsis in almost all 48 patients, and the most common clinical presentation included respiratory deterioration, lethargy, feeding difficulties, and abdominal distension. Non-fungal sepsis had different onset times, with predominantly present early-onset sepsis, and the difference between the fungal and nonfungal groups was significant.

All neonates with fungal sepsis had an umbilical vein catheter, received parenteral nutrition and antibiotic therapy. Almost $90 \%$ of them required mechanical ventilation support, and the mean ventilation support length was 8 days. A quarter of neonates with Candida sepsis received $\mathrm{H} 2$ - receptor blockers and had prolonged hospitalization.

Mechanical ventilation and parenteral nutrition have been used in the Candida sepsis group for a significantly longer period compared to the non-fungal sepsis group. Neonates with Candida sepsis received intravenous immunoglobulins more often compared to the non-fungal sepsis group and they were treated significantly longer in the NICU.

Laboratory findings in neonates with proven sepsis are shown in Tables 4 and 5. Differences between the two observed groups were found for the value of $C$ reactive protein, leukocytes, neutrophils, absolute neutrophil count and platelet count. The most common deviation in neonates with Candida sepsis was presented as an increase in C- reactive protein and leukocytes with thrombocytopenia (Table 5). They also had a significant rate of anemia and leukopenia compared to the control group.

Fluconazole prophylaxis was not included at the time of the study, but Fluconazole therapy was inclu- ded when there was a clinical suspicion of fungal sepsis before blood culture results were received. All blood culture isolates were Candida species group without in- vitro resistance. The duration of Fluconazole therapy averaged $20.6 \pm 6$ days; 11 of them received supportive platelet concentrate; 14 patients received intravenous gammaglobulin. Despite its in-vitro sensitivity, Fluconazole was not effective in the treatment of two neonates and it was replaced by Amphotericin B.

There was no significant difference in mortality rates in the two observed groups. Out of 48 neonates with Candida sepsis, 44 of them survived $(91.7 \%)$, and 4 neonates died $(8.3 \%)$, while the non-fungal sepsis mortality rate was $5.9 \%$. The length of intensive treatment was $38.2 \pm 23.2$ days. Mild toxic hepatitis was recorded as a complication of the total treatment in 8 neonates $(16.7 \%)$ with Candida sepsis, while the same complication in the non-fungal sepsis group was recorded in $5.9 \%$ of cases. This difference between the observed groups had a slight significance.

\section{DISCUSSION}

Regardless of constant progress in the treatment of critically ill neonates globally, sepsis is still one of the major causes of morbidity and mortality in neonates (19). Existing published data have suggested that sepsis causes about $25 \%$ of all neonatal deaths, and mortality due to sepsis has increased by approximately $13.7 \%$ each year over the past 2 decades (19). The diversity of sepsis etiology varies from one region to another and changes over time even in the same place. This is attributed to the changing pattern of antibiotic use and changes in lifestyle and conditions that predispose neonates to infection (20). Fungal sepsis, mainly with Candida species, is an important cause of morbidity and mortality in critically ill neonates $(21,22,23)$. A gradual decrease in susceptibility to routine antibiotic is more highlighted in lower birth weight and premature neonates. The outcomes may be improved by preventative strategies, earlier and accurate diagnosis, and adjunct therapies to combat infection and protect the vulnerable neonates during the infection (7). For these reasons, it is very important to know the local incidence, etiology, resistance and susceptibility of pathogens to antibiotics.

Suspected neonatal sepsis is a common indication for admission to the NICU. The incidence of confirmed neonatal sepsis in our NICU is currently 12 per 1000 live births, which is comparable to other reports and NICU results. Our study has found that candidemia is a common problem in critically ill neonates, with an overall incidence of $5.2 \%$. This data is higher than those in the pieces of literature of European coun- 
tries reporting an incidence of $1.1-1.3 \%$ neonates treated in NICU $(10,11,12)$, and North and South America reporting an incidence of $0.5-1.6 \%(13,14)$, but it is lower than published data in Asia, reporting an incidence of $4-7.7 \%(15,16,17)$. This variability may reflect differences in neonatal clinical practice among countries, as well as in the design of the study and patients involved in it. In our study, neonates with Candida sepsis were equally distributed by gender, which is generally consistent with the published literature, but sometimes reportedly preferred boys (3-6). Almost 90\% were premature neonates, while over $80 \%$ were with low birth weights. That is the mostcommon result in other reports, with the predominance of very preterm neonates (below 32 gestational weeks) and very low birth weight (below $1500 \mathrm{~g})(3,4,5)$. In our study very preterm and extremely preterm neonates were significantly more frequent in the group of Candida sepsis compared to the non-fungal sepsis group. All low birth weight categories were more frequently represented in neonates with Candida sepsis compared with the non-fungal sepsis group.

Neonatal disease severity scoring systems showed significantly higher values in neonates with Candida sepsis in relation to the non-fungal sepsis group. Severe clinical presentation of neonates with proven sepsis via positive blood culture was demonstrated by the necessarily applied supportive therapy. The risk for fungal sepsis in neonates is high due to aggressive and invasive treatment, such as central venous catheters, mechanical ventilation, parenteral nutrition and prolonged hospitalization (24). In our study, all patients with Candida sepsis had an umbilical vein catheter, received parenteral nutrition and antibiotic therapy. Almost $90 \%$ of them required mechanical ventilation, and the mean mechanical ventilation support length was 8 days. Central venous catheters and parenteral nutrition are reported to be a major risk factor for infection with non-albicans Candida species, both of which predispose to the formation of catheter biofilms. Amino acids from parenteral nutrition mediate cell differentiation, that could explain the high incidence of Candida sepsis in neonates with a central venous catheter receiving amino acid-rich parenteral nutrition (24). Mechanical ventilation has been described as a risk factor for neonatal fungal sepsis, although there are also very rare reports describing non- invasive support with continuous positive airway pressure as a risk factor (6). Most of our patients $(89.6 \%)$ were on mechanical ventilation support.

Commonly, fungal sepsis is reported as the late-onset sepsis, as a study of Ozkan et al., 2014 (4), reported neonatal non-fungal sepsis more frequently than candidemia, with Candida sepsis manifesting as late-onset sepsis or very late-onset sepsis and without early-onset Candida sepsis. Mehara et al., 2013 (25) and Bizzarro et al., 2015 (20), also reported Candida sepsis more often as late-onset than early-onset neonatal sepsis. In our study, Candida sepsis manifested as late sepsis in almost all 48 patients, while non-fungal sepsis had different onset times, and it was predominantly $(60 \%)$ early-onset.

Signs and symptoms of neonatal fungal sepsis are often subtle and non-specific (16), but enough to suspect, and as we wait for the results of blood culture, we need to use laboratory findings as a diagnostic tool in order not to be late with the right therapy. Laboratory studies used to evaluate neonatal sepsis include a complete blood cell count and differential, measurement of levels of C-reactive protein and other infection markers (26). Laboratory findings in our neonates with Candida sepsis showed differences in infection markers compared to the non-fungal group. The most common abnormalities in neonates with Candida sepsis were an increase in $\mathrm{C}$ - reactive protein and leukocytes with thrombocytopenia. They also had a significant rate of anemia and leukopenia compared to the control group. Reports of other mainly state thrombocytopenia (16).

All blood culture isolates in our study were from Candida spp. group without in vitro resistance, which is consistent with some published studies (3-6). There are regional differences in the incidence of the most common Candida species. Through a systematic literature review, we have found out that four Candida species (C. albicans, C. parapsilosis complex, C. tropicalisi C. glabrata complex) are associated with more than $95 \%$ cases of neonatal candidemia, but the distribution of these four species is different. In general, Candida albicans was dominantly isolated in Europe (4-7) and North and South America (13, 14), and Candida non-albicans were dominant in Asia $(15,16,17)$.

However, more recent studies report the constant growth of non-albicans Candida species, with a frequency of over $50 \%$ in some NICU. This is partly associated with an increase in the clinical use of the azole antifungal therapy and prophylaxis $(21,22,23)$, although this has also been reported in hospitals where Fluconazole has rarely been used for prophylaxis and therapy (4). Even some earlier reports, such as the Helsinki report (27), mention the Fluconazole resistance phenomenon in a $\mathrm{C}$ parapsilosis after more than 10 years of Fluconazole prophylaxis in NICU. Routine use of Fluconazole prophylaxis in this constellation is questionable.

The mortality rate in our neonates with Candida sepsis was $8.3 \%$, while the non-fungal sepsis mortality rate was $5.9 \%$, therefore without significant difference. The mortality rate due to neonatal fungal sepsis varied, and it was mostly high. It goes from $40 \%(4,6)$ up to 
$75 \%$ (28), and is considered low if it was below 20\% (29). Mortality rates in other studies are mainly related to known risk factors and their correlation. The length of intensive treatment was $38.2 \pm 23.2$ days. There was no consensus concerning the duration of therapy, and Fluconazole and Amphotericin B appear to be safe and effective for the treatment of systemic candidal infection in the neonates although more data are required regarding its use in very low birth weight neonates (3). In our study, mild toxic hepatitis was recorded as a complication of the total treatment in 8 neonates $(16.7 \%)$ with Candida sepsis, while the same complication in the non-fungal sepsis group was recorded in $5.9 \%$ of cases. This difference between the observed groups had a slight significance. There are not many reports of treatment complications, mostly reporting mortality rates.

\section{CONCLUSION}

Neonatal Candida sepsis has a risky clinical course and outcome. It endangers life, complicates treatment, prolongs NICU stay, increases costs and mortality. Recovery of these neonates depends on timely clinical suspicion, adequate treatment, and supervision. Antifungal susceptibility is also important, which requires monitoring of local epidemiological data to improve treatment.

Candida sepsis is an important cause of morbidity and mortality in critically ill neonates. The incidence at our hospital is 5.2 per 100 admissions to the Neonatal Intensive Care Unit. Perinatal risk factors for fungal sepsis are prematurity and low birth weight. The umbilical vein catheter, parenteral nutrition, antibiotic therapy, and mechanical ventilation are also considered to be significant risk factors. We can conclude that Candi- da sepsis is an iatrogenic disease of modern neonatal intensive care and healthcare-associated infections that deserves urgent attention for its prevention as well as an effective treatment in order to minimize neonatal morbidity and mortality.

\section{Abbreviations}

NICU - Neonatal intensive care unit

SNAP-PE - Score for Neonatal Acute Physiology - Perinatal Extension score

CRIB II - Clinical Risk Index for Babies score

CRP - C-reactive protein

CBC - Complete blood cell

WBC - white blood cell

ANC - absolute neutrophil count

Htc - hematocrit ratio

ITR (I/T ratio) — immature -to-total neutrophil

SD - standard deviation

GA - Gestational age

BW - Birth weight

AS - Apgar score

PRM - premature rupture of membrane

MV - mechanical ventilation

EOS - early-onset sepsis;

LOS - late-onset sepsis

Acknowledgment: None

Conflict of Interests: The authors declare that there are no conflicts of interest related to this article.

Funding: None

\section{Licensing}

This work is licensed under a Creative Commons Attribution 4.0 International (CC BY 4.0) License.

\title{
Sažetak
}

\section{KLINIČKE I LABORATORIJSKE KARAKTERISTIKE NEONATALNE SEPSE IZAZVANE KANDIDOM}

\author{
Hadzic Devleta, ${ }^{1}$ Skokic Fahrija, ${ }^{1}$ Brkic Selmira, ${ }^{2}$ Saracevic Amina ${ }^{1}$
}

${ }^{1}$ Pediatric Clinic, University Clinical Center of Tuzla, Bosnia and Herzegovina

${ }^{2}$ Faculty of Medicine University of Tuzla, Bosnia and Herzegovina

Uvod: Neprestani napredak u neonatologiji povećava preživljavanje nedonoščadi uz primenu višestrukih invazivnih postupaka, što povećava rizik od infekcije, i shodno tome gljivične sepse. Candida je dominantan uzročnik uz porast rezistentnih ne-albicans vrsta. Smrtnost je visoka i zahteva pravovremenu kliničku sumnju i adekvatan tretman da bi se sprečio loš ishod.

Cilj studije bio je analiza kliničkih i laboratorijskih karakteristika Candida sepse u odnosu na bakterij- ske sepse kod novorođenčadi lečene na odeljenju intenzivne nege. Metode: Restrospektivna trogodišnja kohortna studija sprovedena na Odeljenju intenzivne nege Klinike za dečije bolesti Tuzla (2016-2018) analizirala je kliničke i laboratorijske karakteristike novorođenčad sa Candida sepsom, dokazanom pozitivnom hemokulturom. Kontrolnu grupu činila su novorođenčad koja su u istom periodu lečena zbog dokazane bakterijske sepse. U statističkoj obradi korištene su stan- 
dardne metode, a istraživanje je odobrio Etički komitet ustanove.

Rezultati: Od 921 novorođenčeta koje je tretirano u trogodišnjem periodu, Candida sepsa potvrđena hemokulturom pronađena je u 48 (5,2\%). Prematuritet i niska porođajna težina bili su najznačajniji faktori rizika, a pogođena novorođenčad imala su ozbiljniju kliničku sliku, češće su primala parenteralnu prehranu, mehaničku ventilaciju, intravenske gamaglobuline i duže su intenzivno lečena. Candida sepsa manifestovala se uglavnom kao kasna. Od laboratorijskih nalaza ova novorođenčad češće su imala porast CRP, anemiju, odstupanja u broju leukocita i trombocitopeniju. Nije bilo razlike u smrtnosti. Oporavilo se

\section{REFERENCES}

1. Ting JY, Roberts A, Synnes A, Canning R, Bodani J, Monterossa L, et al. Invasive fungal infections in neonates in Canada: epidemiology and outcomes. Pediatr Infect Dis J. 2018; 37(11): 1154-9.

2. Klingspor L, Ullberg M, Rydberg J, Kondori N, Serrander L, Swanberg J, et al. Epidemiology of fungaemia in Sweden: A nationwide retrospective observational survey. Mycoses. 2018; 61(10): 777-85.

3. Caggiano G, Lovero G, De Giglio O, Barbuti G, Montagna O, Laforgia N,et al. Candidemia in the Neonatal Intensive Care Unit: a retrospective, observational survey, and analysis of literature data. Biomed Res Int. 2017; 2017: 7901763. doi: 10.1155/2017/7901763.

4. Ozkan H, Cetinkaya M, Koksal N, Celebi S, Hacimustafaoglu M. Culture-proven neonatal sepsis in preterm infants in a neonatal intensive care unit over a 7 year period: coagulase-negative Staphylococcus as the predominant pathogen. Pediatrics International. 2014; 56(1): 60-6.

5. Kelly M S, Benjamin D K, Smith P B The epidemiology and diagnosis of invasive candidiasis among premature infants. Clin perinatol. 2015; 42(1): 105-17.

6. Ballot D E, Bosman N, Nana T, Ramdin T, Cooper PA. Background changing patterns of neonatal fungal sepsis in a developing country. J Trop Pediatr. 2013; 59(6): 460-4.

7. Autmizguine J, Tan S, Cohen-Wolkowiez M, Cotten CM, Wiederhold N, Goldberg RN, et al. Antifungal susceptibility and clinical outcome in neonatal candidiasis. Pediatr Infect Dis J. 2018; 37(9): 923-9.

8. Chapman B, Slavin M, Marriott D, Halliday C, Kidd $\mathrm{S}$, Arthur I, et al. Changing epidemiology of candidaemia in Australia. J Antimicrob Chemother. 2017; 72(4): 1103-8.

9. Leibovitz E. Strategies for the prevention of neonatal candidiasis. Pediatrics and neonatology. 2012; 53(2): 83-9.

10. Mantadakis E, Pana ZD, Zaoutis T. Candidemia in children: Epidemiology, prevention and management. Mycoses. 2018; 61(9): 614-22.

11. Tortorano AM, Prigitano A, Lazzarini C, Passera M, Deiana ML, Cavinato S, et al. A 1-year prospective survey of candidemia in Italy and changing epidemiology over one decade. Infection. 2013; 41(3): 655-62.
44 novorođenčadi $(91,7 \%)$, dok je $4(8,3 \%)$ umrlo. Antifungalna terapija trajala je 20,6 \pm 6 dana, a intenzivno lečenje 38,2 \pm 23,2 dana i bilo je značajno duže $\mathrm{u}$ odnosu na kontrolnu skupinu. Svi izolati bili su vrste Candida bez in-vitro rezistencije. Kod 8 novorođenčadi (16,7\%) prijavljene su komplikacije tretmana. Zaključak: Candida sepsa u novorođenčadi ugrožava život, otežava lečenje, povećava troškove i smrtnost. Povoljan ishod zavisi od pravovremene kliničke sumnje, adekvatnog lečenja i nadzora. Antifungalna osetljivost takođe je važna i zahteva praćenje lokalne epidemiološke dinamike.

Ključne reči: Candida sepsa, novorođenče, kliničke i laboratorijske karakteristike.

12. Pfaller M, Neofytos D, Diekema D, Azie N, Meier-Kriesche HU, Quan SP et al. Epidemiology and outcomes of candidemia in 3648 patients: data from the Prospective Antifungal Therapy (PATH Alliance) registry, 2004-2008. Diagn Microbiol Infect Dis. 2012; 74(4): 323-31.

13. Robinson J A, Pham H D, Bloom B T, Wittler RR. Risk factors for persistent candidemia infection in a neonatal intensive care unit and its effect on mortality and length of hospitalization. J Perinatol. 2012; 32(8): 621-5.

14. Hoffmann-Santos H D, Paula C R, Yamamoto ACA, Tadano T, Hahn RC. Six-year trend analysis of nosocomial candidemia and risk factors in two intensive care hospitals in Mato Grosso, midwest region of Brazil. Mycopathologia. 2013; 176(5-6): 409-15.

15. Chen IL, Chiu NC, Chi H, Hsu CH, Chang JH, Huang DT, et al. Changing of bloodstream infections in a medical center neonatal intensive care unit. Journal of Microbiology, Immunology and Infection. 2017; 50(4): 514-20.

16. Chaurasia D, Goel M, Dhruw S, Dubey D, Dwivedi R. Changing pattern of neonatal fungal sepsis: a matched case-control study. Natl J Med Allied Sci. 2015; 4(1): 3-7.

17. Wadile R, Bhate V. Study of clinical spectrum and risk factors of neonatal candidemia. Indian J Pathol Microbiol. 2015; 58(4): 472-4.

18. Dorling JS, Field DJ, Manktelow B. Neonatal disease severity scoring systems. Arch Dis Child Fetal Neonatal Ed. 2005; 90(1): 11-6.

19. Afonso EDP, Blot S. Effect of gestational age on the epidemiology of late-onset sepsis in neonatal intensive care units - a review. Expert Rev Anti Infect Ther. 2017; 15(10): 917-24.

20. Bizzarro MJ, Shabanova V, Baltimore RS, Dembry LM, Ehrenkranz RA, Gallagher PG. Neonatal sepsis 2004-2013: The rise and fall of coagulase-negative staphylococci. J Pediatr. 2015; 166(5): 1193-9.

21. Juyal D, Sharma M, Pal S, Rathaur VK, Sharma N. Emergence of non-albicans Candida species in neonatal candidemia. N Am J Med Sci. 2013; 5(9): 541-5.

22. Khan EA, Choudhry S, Fatima M, Batool Z. Clinical spectrum, management and outcome of neonatal candidiasis. J Pak Med Assoc. 2015; 65(11): 1206-9.

23. Pappas PG, Kauffman CA, Andes DR, Clancy CJ, Marr KA, Ostrosky-Zeichner L, et al. Clinical practice guideline for 
the management of candidiasis: 2016 update by the infectious diseases society of America. Clin Infect Dis. 2016; 62(4): e1-50.

24. Hammoud MS, Al-Taiar A, Fouad M, Raina A, Khan Z. Persistent candidemia in neonatal care units: Risk factors and clinical significance. Int J Infect Dis. 2013; 17(8): e624-8.

25. Mehara V, Yadava D, Somania P, Bhatambareb G, Mulyea S, Singh K. Neonatal sepsis in a tertiary care center in central India: microbiological profile, antimicrobial sensitivity pattern and outcome. J Neonatal-Perinatal Med. 2013; 6(2): $165-72$.

26. Hornik CP, Benjamin DK, Becker KC, Benjamin DK $\mathrm{Jr}$, Li J, Clark RH, et al. Use of the complete blood cell count in

\section{Correspondence to/Autor za korespondenciju}

Devleta Hadžić, MD PhD

Pediatric Clinic, University Clinical Center of Tuzla

Prof. Ibre Pasic bb, 75000 Tuzla

Bosnia and Herzegovina

tel: 0038735303733

e-mail: devletahadzic@yahoo.com late-onset neonatal sepsis. Pediatr Infect Dis J. 2012; 31(8): 799-802.

27. Sarvikivi E, Lyytikainen O, Soll DR, Pujol C, Pfaller MA, Richardson $\mathrm{M}$ et al. Emergence of fluconazole resistance in a Candida parapsilosis strain that caused infections in a neonatal intensive care unit. J Clin Microbiol 2005; 43(6): 2729-35.

28. Sardana V, Pandey A, Madan M, SP Goel, Ashish K Asthana. Neonatal candidemia: a changing trend. Indian J Pathol Microbiol 2012; 55(1): 132-3.

29. Rodriguez D, Almirante B, Park BJ, Cuenca-Estrella M, Planes AM, Sanchez F et al. Candidemia in neonatal intensive care units: Barcelona, Spain. Pediatr Infect Dis J. 2006; 25(3): 224-9. 